\title{
REVIEW
}

\section{Epigenetic and metabolic reprogramming of SDH-deficient paragangliomas}

\author{
Sophie Moog1,2, Charlotte Lussey-Lepoutre ${ }^{1,3}$ and Judith Favier1,2 \\ IPARCC, INSERM UMR970, Equipe Labellisée par la Ligue contre le Cancer, Paris, France \\ 2Université de Paris, Paris, France \\ ${ }^{3}$ Department of Nuclear Medicine, Sorbonne University, Pitie-Salpetriere Hospital, Paris, France
}

Correspondence should be addressed to J Favier: judith.favier@inserm.fr

\begin{abstract}
Pheochromocytomas and paragangliomas (PPGL) are rare neuroendocrine tumors arising from the adrenal medulla or extra-adrenal paraganglia. Around $40 \%$ of all cases are caused by a germline mutation in a susceptibility gene, half of which being found in an $S D H x$ gene (SDHA, SDHB, SDHC, SDHD or SDHAF2). They encode the four subunits and assembly factor of succinate dehydrogenase (SDH), a mitochondrial enzyme involved both in the tricarboxylic acid cycle and electron transport chain. SDHx mutations lead to the accumulation of succinate, which acts as an oncometabolite by inhibiting iron(II) and alpha-ketoglutarate-dependent dioxygenases thereby regulating the cell's hypoxic response and epigenetic processes. Moreover, SDHx mutations induce cell metabolic reprogramming and redox imbalance. Major discoveries in PPGL pathophysiology have been made since the initial discovery of SDHD gene mutations in 2000, improving the understanding of their biology and patient management. It indeed provides new opportunities for diagnostic tools and innovative therapeutic targets in order to improve the prognosis of patients affected by these rare tumors, in particular in the context of metastatic diseases associated with SDHB mutations. This review first describes an overview of the pathophysiology and then focuses on clinical implications of the epigenetic and metabolic reprogramming of SDH-deficient PPGL.
\end{abstract}

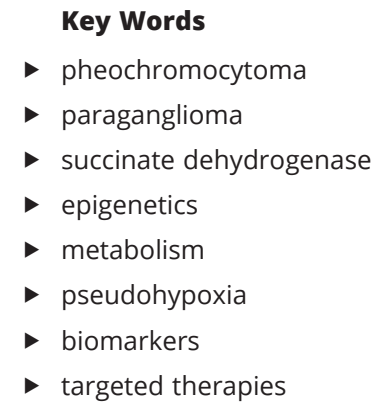

Endocrine-Related Cancer (2020) 27, R451-R463

\section{Introduction}

Pheochromocytomas and paragangliomas (PPGL) are rare neuroendocrine tumors arising from the adrenal medulla or extra-adrenal paraganglia, respectively. Paragangliomas can be found in the sympathetic nervous system of the thorax, abdomen, or pelvis or in the parasympathetic ganglia of the head or neck region. Pheochromocytomas and sympathetic paragangliomas commonly release catecholamines such as epinephrine, norepinephrine or dopamine, which can lead to cardio- or cerebro-vascular complications, whereas head and neck paragangliomas do not (Lenders et al. 2020). Most PPGL are curable by surgery when they are localized, with a recurrence rate estimated at $1 \%$ per year per patient (Amar et al. 2016). However, $10-15 \%$ of PPGL are metastatic, defined by the occurrence of metastatic lesions either in lymph nodes, bones, lungs or liver (Lam 2017), with an overall survival decreasing to $62 \%$ at 5 years, and treatments remaining mainly palliative with a limited efficacy (Hescot et al. 2019). Approximately $70 \%$ of PPGL have a genetic determinism with more than 20 susceptibility genes discovered so far, including germline mutations in about $40 \%$ of cases and somatic mutations in 30\% of cases (Buffet et al. 2020). (c) 2020 Society for Endocrinology Published by Bioscientifica Ltd. Printed in Great Britain 
Mutations in genes encoding the succinate dehydrogenase (SDH) complex are the most prevalent, occurring in SDHA, SDHB, SDHC, SDHD or SDHAF2 genes. Tumors carrying such mutations are classified in the pseudohypoxic expression cluster 1 , together with tumors carrying mutations in VHL (von Hippel-Lindau), FH (fumarate hydratase), DLST (dihydrolipoamide S-succinyltransferase) genes and three genes encoding the malate-aspartate shuttle: GOT2 (glutamic-oxaloacetic transaminase), SLC25A11 (oxoglutarate carrier) and MDH2 (malate deshydrogenase) (Favier et al. 2015, Buffet et al. 2020). Cluster 2 tumors are associated with abnormal kinase signaling and activation of the mTOR pathway and include mutations in RET (multiple endocrine neoplasia type 2), NF1 (neurofibrosis type 1), TMEM127, MAX, MET and HRAS. Cluster 3 is characterized by the activation of the Wnt-signaling pathway with MAML3 (mastermindlike transcriptional coactivator 3) anomalies (Fishbein et al. 2017).

SDHx genes encode the four subunits of SDH in the Tricarboxylic acid (TCA) cycle that also constitutes the mitochondrial complex II of the Electron transfer chain (ETC). It catalyses the oxidation of succinate to fumarate in the former and the transfer of electrons to the ubiquinone pool in the latter. SDHx genes are tumor suppressor genes and follow Knudson's two-hit' model (Knudson 1971), with a germline heterozygous mutation associated with somatic loss of heterozygosity (LOH), leading to a completely abolished (Gimenez-Roqueplo et al. 2001) or highly impaired (Kim et al. 2015) SDH activity. These mutations are transmitted in an autosomal dominant manner, with the exception of SDHD and SDHAF2, which are submitted to maternal imprinting, with only few cases of maternal transmission described so far for SDHD (Burnichon et al. 2017). SDHx mutations are associated with different phenotypes regarding penetrance, manifestations and rate of malignancy. $S D H B$ mutations lead to metastatic evolution in $50 \%$ of cases, with a penetrance of $50 \%$ at age 50 while $S D H D$ mutations mainly lead to multiple cervical paragangliomas with a greater penetrance of up to 80\% (Benn et al. 2006, Amar et al. 2007, Burnichon et al. 2009, Buffet et al. 2020). SDHA, SDHC and SDHAF2 are scarcer. Around 40\% of all PPGL patients carry a germline mutation in a susceptibility gene, half of which being found in an SDHx gene. Genetic counselling and testing are therefore recommended for all PPGL patients (Lenders et al. 2020), promoting the improvement of clinical outcome in patients carrying an SDHx or a VHL mutation (Buffet et al. 2019). Moreover, identification of one of these germline mutations allows to propose a genetic counselling and a pre-symptomatic screening to relatives, in order to include them in an appropriate follow-up protocol (Buffet et al. 2020).

Metabolic reprogramming is one of the eight hallmarks of cancers defined by Weinberg and Hanahan (Hanahan \& Weinberg 2011), as first suggested by Otto Warburg in 1926 with his hypothesis that a direct link existed between mitochondrial dysfunction and cancer (Warburg 1956). Since the initial discovery of SDHD gene mutations in 2000 (Baysal et al. 2000), studies on the pathophysiology of $S D H$-related PPGL have led to major discoveries, improving the understanding of their biology and patient management and contributing to the extension of the field of oncometabolism. Comprehension of these pathophysiological characteristics provides new opportunities for diagnostic and innovative therapeutic strategies in order to improve the prognosis of patients affected by these rare diseases, in particular in the context of metastatic forms associated with $S D H B$ mutations. This review provides an overview of the pathophysiology and then focuses on clinical implications of the epigenetic and metabolic reprogramming of SDH-deficient PPGL.

\section{Metabolic consequences of SDH deficiency and oncogenesis}

Mutations in genes encoding SDH lead to the loss of SDH enzymatic activity and therefore to the interruption of the TCA cycle. To sustain cell proliferation, in this highly compromised metabolic context, SDH-deficient cells consume extracellular pyruvate and activate pyruvate carboxylation to re-supply the depleted pool of aspartate that is further used to provide amino and nucleic acids (Cardaci et al. 2015, Lussey-Lepoutre et al. 2015). Recently, several studies evaluating the respiration and mitochondrial complexes activity of different SDHdeficient cell types revealed some intriguing data that might be a first step in the understanding of the tissue specificity of tumor development in SDH-mutated patients. Indeed, while both respiration of intact cells and complex I-specific activity were found to be lower in SDH-deficient cells compared with WT adrenal fibroblast (Kručková et al. 2020), renal (Cardaci et al. 2015, Lorendeau et al. 2017) and breast epithelial cells (Bezawork-Geleta et al. 2018), it is not the case in a chromaffin cell-derived model. This model retains complex I function and a respiratory activity comparable to WT cells, thereby maintaining the ability to oxidise NADH within the ETC (Klučková et al. 2020). These data showed that in contrast to models of 


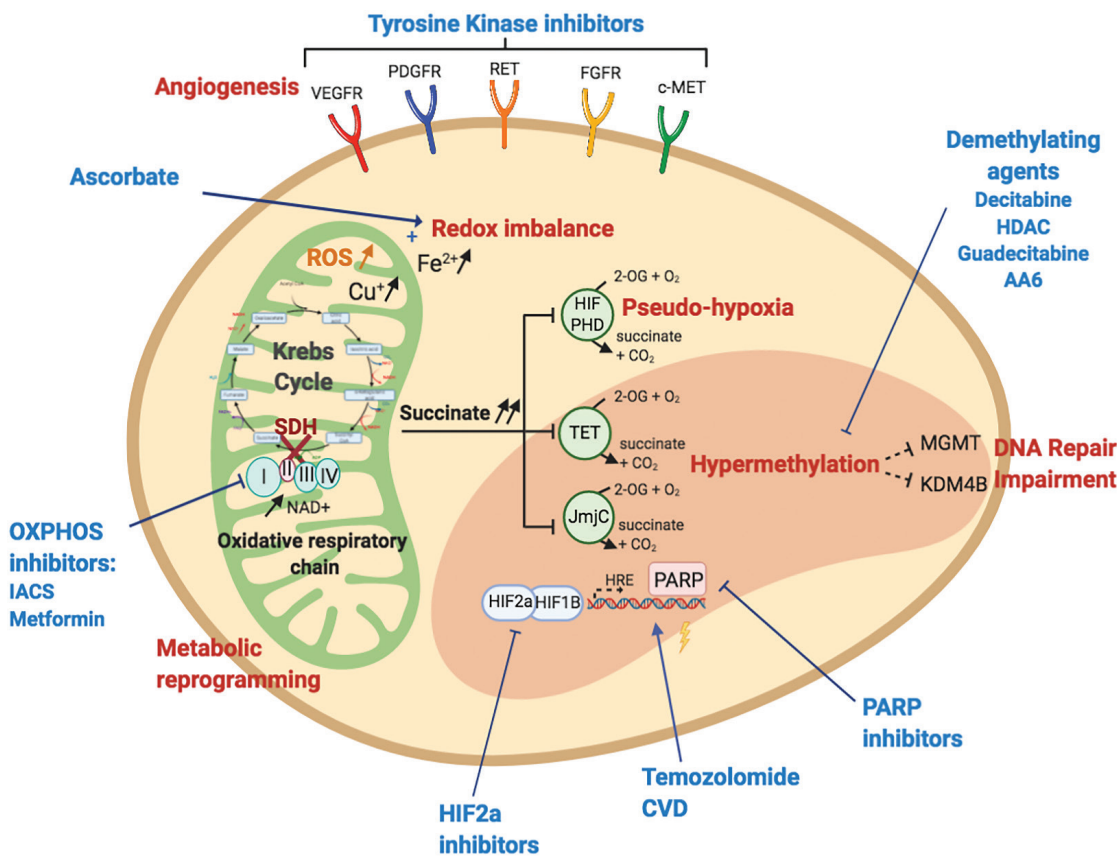

\section{Figure 1}

Epigenetic and metabolic reprogramming of SDH-deficient pheochromocytomas and paragangliomas and their potential treatments. AA6, alpha-ketoglutarate-dependent dehydrogenase inhibitor; 2-OG, alphaketoglutarate; C-MET, hepatocyte growth factor receptor; CVD, cyclophosphamide-dacarbazinevincristine; FGFR, Fibroblast growth factor receptor; HDAC, histone deacetylase; HIF, hypoxia-inducible factors; HIF-PHD, hypoxiainducible factors prolyl hydroxylase; HRE, hypoxia-inducible factors response elements; MGMT, O(6)-methylguanine-DNAmethyltransferase; OXPHOS, oxidative phosphorylation; PARP, Poly(ADP)-ribose polymerase; PDGFR, platelet-derived growth factor receptor; RET, rearranged during transfection; ROS, reactive oxygen species; SDH, succinate deshydrogenase; TET, ten-eleven translocation enzyme; VEGFR, vascular endothelial growth factor receptor.
SDH deficiency based on epithelial cells, a chromaffin cell model preserves some aspects of metabolic 'health', which could form the basis of cell specificity of this rare tumor type.

The main consequence of the truncated TCA cycle is the accumulation of SDH substrate, succinate (Pollard et al. 2005), which is thought to be the major actor of SDHrelated oncogenic processes (Fig. 1). Indeed, it has been demonstrated that succinate can act as an oncometabolite by inhibiting iron(II) and alpha-ketoglutarate-dependent $(\alpha-K G)$ dioxygenases, a large family of enzymes that catalyze the hydroxylation of a wide range of organic targets (Islam et al. 2018). Although it is still debated, ROS accumulation together with iron overload is also suspected to participate to this tumorigenic pathway and further inhibit $\alpha$ KG-dioxygenases. Discrepant data have been published with some studies showing ROS increase (Guzy et al. 2008, Liu et al. 2020) and others not (Selak et al. 2006, Guzy et al. 2008). One hypothesis is that such differences may actually reflect the heterogeneity of the phenotype linked to the different subtypes of SDH subunits, with a general consensus that SDHB-mutated cells do show increased oxidative stress. Members of the $\alpha$-KG-dioxygenases family that regulate the cell's hypoxic response and epigenetic processes, particularly the demethylation of histones and DNA, seem to play a particularly important role in SDH-related tumorigenesis. These enzymes are dependent on molecular oxygen and $\alpha-K G$ as necessary substrates, and use iron and ascorbate as cofactors, making them critical in the processes of metabolic sensing.

\section{Pseudohypoxia}

Their role as oxygen sensor is mediated by the hypoxiainducible factors (HIF) prolyl hydroxylases (PHD 1-3) that regulate HIFs stability. In normoxic conditions, PHD enzymes hydroxylate the $\alpha$ subunits of hypoxia-inducible factors (HIF1 and HIF2) on two highly conserved proline residues, making their recognition by von Hippel Lindau protein (pVHL) possible. pVHL is a E3 ubiquitin ligase that will then promote their ubiquitination and subsequent degradation by the proteasome. Being dependent on oxygen to be fully active, PHDs are inhibited when oxygen concentrations fall in hypoxic conditions; HIF as can therefore escape from their proteasome destiny and translocate to the nucleus where they form an active transcription factor following their heterodimerization with their $\beta$ counterpart, namely the aryl hydrocarbon receptor nuclear translocator (ARNT or HIF1 $\beta$ ). In hereditary PPGL, as in clear cell renal cell carcinoma (ccRCC), activation of HIFs occurs even in the presence of oxygen, through the process of pseudohypoxia. This molecular or metabolic activation of the hypoxic response can be mediated either directly by loss-of-function mutations (such as tumors caused by germline or somatic inactivating mutations of the $V H L$ gene) or through their metabolic consequences. In $S D H$ - and $F H$-mutated PPGL, 
the accumulation of succinate and fumarate respectively promotes the inhibition of PHDs and a pseudo-hypoxic signaling (Briere et al. 2005, Pollard et al. 2005, Selak et al. 2005, Letouze et al. 2013). The wide range of HIF target genes make this response critical for many cellular functions and participate to the occurrence of tumors through many aspects such as metabolic adaptation (glycolytic switch), proliferation, regulation of cell death, angiogenesis, modification of the extracellular matrix components, acquisition of mesenchymal hallmarks (Favier \& Gimenez-Roqueplo 2010).

\section{Epigenetic reprogramming}

Another class of $\alpha$-KG-dependent dioxygenases that were demonstrated to be inhibited by oncometabolites are the DNA and histone demethylases: TET dioxygenases that hydroxylate DNA methylated cytosines $(5 \mathrm{mC})$ into $5 \mathrm{hmC}$ and JmjC-domain containing histone lysine demethylases (KDM) (Cervera et al. 2009). In PPGL as in GIST, SDHx mutations were shown to promote a massive hypermethylator phenotype. Several groups, including ours, studied the methylome of these oncometabolitedriven tumors and reported enhanced DNA methylation in and outside CpG islands (Killian et al. 2013, Letouze et al. 2013). Interestingly, SDHB-deficient PPGL displayed higher global methylation levels than other subtypes of $S D H$-deficient tumors (with mutations in SDHA, C or $D$ ), suggesting that epigenetic reprogramming may participate to the increased metastatic capacities of $S D H B$ mutated tumors. Recently, we were able, using oxidative reduced representation bisulfite sequencing (oxRRBS), to demonstrate that SDHB-mutated PPGL did display lower levels of $5 \mathrm{hmC}$ than NF1-mutated tumors (Morin et al. 2020). Moreover, we showed that hypermethylated DNA sequences were enriched in polycomb repressor complex 2 (PRC2) target genes, albeit independently of PRC2 activity. These observations revealed a tropism of TET enzymes for PRC2 targeted chromatin regions, thereby linking the hypermethylator phenotype of a de-differentiation process. Using functional assays in an $S d h b$-deficient immortalized mouse chromaffin cell line, this study provided the first demonstration that TET-mediated DNA hypermethylation indeed promoted a massive transcriptomic reprogramming, but that the synergy between these epigenetic modifications and a HIF2 $\alpha$-mediated pseudo-hypoxic response was required to promote the invasive and the mesenchymal phenotypes of $S d h b$-deficient cells.

\section{Metabolic and epigenetic biomarkers}

Rapid identification of SDH deficiency is important at various levels, by accelerating genetic testing or facilitating the interpretation of genetic variations in $S D H x$ genes provided by next-generation sequencing (NGS) (Toledo \& Dahia 2015). Moreover, it can impact patient management by considering the higher risk of metastasis of $S D H B$ related tumors, the high rate of multiple cervical PGL for SDHD-mutated patients and driving therapeutic choices for inoperable and metastatic patients. Thus, several biomarkers have been developed based on assessment of protein expression, functionality and its metabolic and/or epigenetic consequences (Table 1).

\section{Enzyme functionality and metabolomics}

For SDH expression, the routinely method employed is SDHB immunohistochemistry (IHC) performed on formalin-fixed paraffin-embedded (FFPE) tumors that predicts $S D H x$ mutations with a good sensitivity, specificity and reproducibility among expert endocrine pathologists in PPGL (van Nederveen et al. 2009, Gill et al. 2010, Papathomas et al. 2015) and in other tumors as GIST (Gaal et al. 2011, Oudijk et al. 2013) and kidney cancers (Gill et al. 2011). The mitochondrial-specific granular staining is lost in tumor cells for all subtypes of SDHx mutations (SDHA, SDHB, SDHC, SDHD and SDHAF2) while it is maintained in stromal cells such as endothelial cells, adipocytes or sustentacular cells, providing internal positive controls (van Nederveen et al. 2009, Gill et al. 2010). SDHA IHC is also a valuable method in tumors with a negative SDHB immunostaining to specifically identify SDHA-related tumors, as it is negative for $S D H A$ mutations but positive for all other $S D H$-related tumors (Korpershoek et al. 2011). In some cases, especially SDHDrelated PGL, SDHB IHC may fail because of a weak diffuse cytoplasmic blush that should be considered as negative but can be misinterpreted (Gill et al. 2010, Papathomas et al. 2015). In that context, SDHD IHC can be useful, with a mirror result, that is negative in non-SDHx PGL and a positive labeling characterized by a cytoplasmic diffuse signal with patchy accumulation in $\mathrm{SDH}$-mutated PGL (Menara et al. 2015).

The direct method to assess SDH functionality is the quantification of SDH activity on fresh frozen tumor samples using a spectrophotometric assay (Rustin et al. 1994). Measurement of Krebs cycles metabolites by liquid chromatography-mass spectrometry (LC-MS/MS) is 
Table 1 Metabolic and epigenetic biomarkers of SDH-deficient pheochromocytomas and paragangliomas.

\begin{tabular}{|c|c|c|c|c|}
\hline Type & Interpretation & Sn/Sp & Current use & References \\
\hline \multicolumn{5}{|l|}{ Immunohistochemistry } \\
\hline SDHB & $\begin{array}{l}\text { Mitochondrial-specific granular } \\
\text { staining lost in tumor cells of } \\
\text { non-SDHx mutated tumors. } \\
\text { Negative in tumors cells with all } \\
\text { types of SDHx mutations (SDHA, } \\
\text { SDHB, SDHC, SDHD and SDHAF2). } \\
\text { Weak diffuse cytosolic staining } \\
\text { should be considered as negative. }\end{array}$ & $\begin{array}{l}\text { 94\%/84\% } \\
\text { (Papathomas et al. } \\
\text { 2015) }\end{array}$ & Clinical & $\begin{array}{l}\text { van Nederveen et al. } \\
\text { 2009, Gill et al. 2010, } \\
\text { Papathomas et al. } \\
2015\end{array}$ \\
\hline SDHA & $\begin{array}{l}\text { Negative in SDHA-mutated tumors } \\
\text { but positive in all other SDHx- or } \\
\text { non-SDHx-mutated tumors }\end{array}$ & $\begin{array}{l}75 \% / 93 \% \\
\text { (Papathomas et al. } \\
\text { 2015) }\end{array}$ & Clinical & $\begin{array}{l}\text { Korpershoek et al. } \\
\text { 2011, Papathomas } \\
\text { et al. } 2015\end{array}$ \\
\hline SDHD & $\begin{array}{l}\text { Used in case of SDHB IHC } \\
\text { interpretation (such as weak } \\
\text { diffuse staining); negative in } \\
\text { non-n-SDHx PGL and positive } \\
\text { labeling (cytoplasmic diffuse } \\
\text { signal with patchy accumulation) } \\
\text { in SDHx-mutated PGL }\end{array}$ & $\begin{array}{l}\text { 96\%/97\% (Menara } \\
\text { et al. 2015) }\end{array}$ & Research & Menara et al. 2015 \\
\hline DNA methylation: 5hmc & $\begin{array}{l}\text { 5hmC staining inferior (or absent) } \\
\text { in the nuclei of SDHx-mutated } \\
\text { tumor cells compared with } \\
\text { endothelial or sustentacular cells }\end{array}$ & Not available & Research & $\begin{array}{l}\text { Letouze et al. } 2013, \\
\text { Hoekstra et al. } 2015\end{array}$ \\
\hline $\begin{array}{l}\text { Histone methylation: } \\
\text { H3K4me3, H3K9me3, } \\
\text { H3K27me3 }\end{array}$ & $\begin{array}{l}\text { Increase in } \mathrm{H} 3 \mathrm{~K} 9 \mathrm{me} 3 \text { in } \mathrm{SDHX}- \\
\text { related tumors (no change in } \\
\mathrm{H} 3 \mathrm{~K} 4 \mathrm{me} 3 \text { and } \mathrm{H} 3 \mathrm{~K} 27 \mathrm{me} 3 \text { ) }\end{array}$ & Not available & Research & Letouze et al. 2013 \\
\hline $\begin{array}{l}\text { Succinate in vitro } \\
\text { (LC-MS/MS) }\end{array}$ & $\begin{array}{l}\text { Accumulation of succinate in case } \\
\text { of an SDHx mutation with very low } \\
\text { levels of fumarate. (high succinate } \\
\text { to fumarate ratio) }\end{array}$ & $\begin{array}{l}88 \% / 99.2 \% \text { (Wallace } \\
\text { et al. 2020) }\end{array}$ & Research & $\begin{array}{l}\text { Pollard et al. 2005, } \\
\text { Rao et al. } 2013, \\
\text { Richter et al. } 2014, \\
\text { Imperiale et al. } 2015 \text {, } \\
\text { Wallace et al. } 2020\end{array}$ \\
\hline Succinate in vivo ( $\left.{ }^{1} \mathrm{H}-\mathrm{MRS}\right)$ & $\begin{array}{l}\text { Accumulation of succinate in } \\
\text { tumor in case of an SDHX } \\
\text { mutation }\end{array}$ & $\begin{array}{l}\text { 87\%/100\% (Lussey- } \\
\text { Lepoutre et al. 2020) }\end{array}$ & Research/clinical & $\begin{array}{l}\text { Varoquaux et al. } \\
\text { 2015, Lussey- } \\
\text { Lepoutre et al. 2016, } \\
\text { 2020, Casey et al. } \\
2018\end{array}$ \\
\hline
\end{tabular}

5hmc, 5-methylcytosine; ${ }^{1} \mathrm{H}$-MRS, proton magnetic resonance spectroscopy; IHC, immunohistochemistry; LC-MS/MS, liquid chromatography with mass spectrometry; SDH, succinate deshydrogenase; Sn, sensitivity; Sp, specificity.

another valuable method (Pollard et al. 2005, Rao et al. 2013, Richter et al. 2014, Imperiale et al. 2015) to assess the consequences of loss of enzymatic activity. Metabolic profiling of $S D H$-mutated PGL show important accumulation of succinate (SDH substrate), with concentrations up to 100-fold higher than tumors without SDHx mutations and very low levels of its product, fumarate. Thus, the tissue-specific succinate to fumarate ratio (SFR) has a good sensitivity and a recent study showed a higher specificity than SDHB IHC to detect SDHx mutations on fresh frozen tumors and FFPE (Wallace et al. 2020). Interestingly, SFR appeared particularly high in SDHB-mutated and metastatic PGL but lower in head and neck PGL (Richter et al. 2014). Other TCA cycle metabolites are also significantly impacted in $\mathrm{SDH}$ mutated PGL: a decrease in isocitrate, cis-aconate (Richter et al. 2014), aspartate and glutamate (Imperiale et al. 2015) may also be used as biomarkers but above all can improve understanding of metabolic reprogramming. Indeed, decrease of aspartate has been elucidated by in vitro ${ }^{13} \mathrm{C}$-glucose fluxes experiments as a consequence of the high dependence of SDH-deficient cells upon mitochondrial aspartate for cellular anabolism, suggesting novel therapeutic perspectives (Lussey-Lepoutre et al. 2015).

Altogether, metabolomic profiling and IHC provide valuable biomarkers of $S D H x$ mutation but rely on the availability of tissue from the resected tumor. Because of the high vascularization of these tumors (Favier et al. 2009) and the secretion of catecholamines, the recourse to a biopsy is a contraindication and the surgical removal of the lesion is not always feasible.

Data on whether circulating or urinary levels of succinate are efficiently measurable in patients with 
germline SDHx variants are still scarce. Using gas chromatography-mass spectrometry (GC-MS), Hobert et al. reported high succinate levels in the plasma of patients with SDHB- (1/1) and SDHD-(2/5) associated PPGL (Hobert et al. 2012). Assessment of SFR in plasma samples of patients with PPGL was then reported by Lendvei et al. but again not fully conclusive (Lendvai et al. 2014). Therefore, there was a need for a specific tumor biomarker allowing the characterization of inoperable tumors and suspicious lesions.

Succinate shows a characteristic peak at $2.44 \mathrm{ppm}$ in spectral analysis that can be detected noninvasively by in vivo proton magnetic resonance spectroscopy ( $\left.{ }^{1} \mathrm{H}-\mathrm{MRS}\right)$. ${ }^{1} \mathrm{H}$-MRS is a MRI sequence specific for the observation of tissue compounds after elimination of water protons signal. ${ }^{1} \mathrm{H}$-MRS has been initially developed in the field of cerebral tumors, especially gliomas, that have recurrent somatic mutations in one of the isocitrate dehydrogenase genes (IDH1 and IDH2) leading to the overproduction of 2-hydroxyglutarate (2-HG), detectable in vivo by ${ }^{1} \mathrm{H}-\mathrm{MRS}$ (Andronesi et al. 2012, Choi et al. 2012). Detection of succinate accumulation in vivo as a biomarker for the presence of an SDHx mutation is also feasible and has been developed in recent years (Varoquaux et al. 2015, Lussey-Lepoutre et al. 2016, 2020, Casey et al. 2018).

We previously developed a pulse ${ }^{1} \mathrm{H}$-MRS sequence to measure succinate in an allografted mouse model of $S d h b$-deficient tumors and in a pilot study performed in nine patients with PPGL (five with SDHx mutations and four sporadic cases). We demonstrated the feasibility of detecting succinate in vivo by ${ }^{1} \mathrm{H}-\mathrm{MRS}$ as a very specific biomarker of SDHx mutations (Lussey-Lepoutre et al. 2016). The diagnostic performance of ${ }^{1} \mathrm{H}-\mathrm{MRS}$ was subsequently validated on a prospective cohort of patients carrying 50 PPGL (Lussey-Lepoutre et al. 2020), validating the good sensitivity (87\%) and the perfect specificity (100\%) of this technique, in particular for PGL of the head and neck. The limits of ${ }^{1} \mathrm{H}-\mathrm{MRS}$ are mainly the size of the tumor (which determines the size of the voxel) and the presence of necrosis in the tumor. On the other hand, sensitivity and specificity remain identical whatever the subtype of mutation (SDHA, B, C or D). ${ }^{1} \mathrm{H}$-MRS can also be applied to other tumors with SDHx deficiency such as GIST, as well as metastases of PPGL (Casey et al. 2018). Moreover, animal experiments demonstrated that the area under the succinate peak of the ${ }^{1} \mathrm{H}-\mathrm{MRS}$ spectra in vivo was correlated with the concentrations of succinate measured in the resected tumors by GC-MS in vitro, allowing quantifying succinate levels in vivo (Lussey-Lepoutre et al. 2016). Future studies are needed to show whether this correlation holds also in patients. If it turned out to be the case, it could provide a quantifiable surrogate marker of early response to treatment in $S D H x$-related PPGL patients.

\section{Molecular biomarkers: when epigenetics enters the game}

Epigenetic reprogramming being a major consequence of SDH deficiency, it rapidly emerged as a hallmark of choice to be used to develop specific biomarkers, either of $S D H x$ mutations or of metastatic disease. Specific antibodies have been developed to detect the different states of DNA cytosines $(5 \mathrm{mC}$ or $5 \mathrm{hmC})$ or the methylation marks of histones (H3K9me2, H3K9me3, H3K27me2, H3K27me3, H3K4me3). These antibodies have been used on paraffin embedded PPGL (Letouze et al. 2013, Hoekstra et al. 2015) or GIST (Killian et al. 2013) and correlated with the genetic status of the tumors. In PPGL tumors, we first evaluated the levels of $5 \mathrm{mC}, 5 \mathrm{hmC}, \mathrm{H} 3 \mathrm{~K} 9 \mathrm{me} 3$ and H3K27me3 in 40 tumor samples including $16 \mathrm{SDH}$-mutated. We showed that $5 \mathrm{mC}$ staining was not different between the different tumors, while histone methylation was indeed increased in SDH-related tumors. However, such immunostainings were neither specific nor sensitive enough to be used as biomarkers. In contrast, low $5 \mathrm{hmC}$ levels in the nuclei of tumor cells were detected in all $S D H$-mutated and in only 6/24 non-SDH samples. Following these initial observations, Hoekstra et al. evaluated these markers in a large collection of 134 PPGL (including 75 SDHx-mutated) and also concluded that $5 \mathrm{hmC}$ was significantly lower or even absent in the case of an SDHx gene mutation (Hoekstra et al. 2015). Interestingly, it is worth noting that low $5 \mathrm{hmC}$ is detected not only in SDH-deficient tumors but also in PPGL carrying other types of mutations affecting mitochondrial proteins: $F H$ (Castro-Vega et al. 2014, Hoekstra et al. 2015), SLC25A11 (Buffet et al. 2018), and DLST (Buffet et al. personal communication).

Global DNA methylation was also evaluated in large collections of tumors to identify hypermethylated CpG that may be exploitable as predictors of genetic status or of the metastatic potential of a primary PPGL (Letouze et al. 2013, de Cubas et al. 2015). Hypermethylation of PNMT was reported in SDHB-related PPGLs while RET- and NF1mutated PPGL showed hypomethylation and VHL-related one, hemimethylation. These observations are of particular interest because of the role of PMNT in catecholamine biosynthesis and explain the neurochemical phenotypes of these different subsets of tumors, with $\mathrm{SDH}$ and VHL-deficient PPGL showing a noradrenergic secretion (Eisenhofer et al. 2017). Hypermethylation of RDBP 
(negative elongation factor complex member E) was detected as a specific biomarker of metastatic tumors, independently of their genetic status (de Cubas et al. 2015).

\section{Therapeutics perspectives}

Around $10-15 \%$ of PPGLs will become metastatic and have a poor prognosis with a mortality rate of $37 \%$ at 5 years (Hamidi et al. 2017). Unfortunately, there are limited options for these cases, based on metabolic radiotherapy or chemotherapy, with imperfect efficacy (Baudin et al. 2014). Knowledge on PPGL biology has recently been turned upside down by genomics and metabolomics data, making it possible to envisage the use of targeted therapies and precision medicine (Favier et al. 2015) (Table 2). This review being focused on $\mathrm{SDH}$ mutated PPGL based on new discoveries, especially those depending on epigenetic and metabolic reprograming, we will not discuss several potentially promising therapies for PPGL such as radionuclide therapy, mTOR inhibitors, somatostatin analog or immunotherapy.

\section{Targeting angiogenesis}

SDH-mutated tumors being highly vascularized, the use of antiangiogenic therapies that block the VEGF pathway are an important hope for metastatic patients and in particular for the very aggressive forms linked to SDHB. In addition to their antiangiogenic properties, tyrosine kinase inhibitor (TKI) can also inhibit other receptors such as fibroblast growth factors receptor (FGFR) or c-met receptors, which may prevent tumor invasiveness and metastases. A recent and complete overview of antiangiogenic therapies can be found in Jimenez et al. (2020). Several retrospective studies, mostly with sunitinib (TKI targeting VEGFR, PDGFR, RET and c-kit), seem promising and this drug is currently being evaluated in prospective trials. The phase II clinical SNIPP study evaluated sunitinib with $50 \mathrm{mg}$ in 23 patients and found a disease control rate of 83\% (95\% CI: 56-93\%), a progression-free survival (PFS) of 13.4 months (95\% CI: 5.3-24.6 months) but with a very low objective response rate (O'Kane et al. 2019). The results of the first randomized trial of 78 metastatic PPGL patients with sunitinib $37.5 \mathrm{mg}$ should be available soon (FIRSTMAPPP, NCT01371201). Others TKI have been or are currently evaluated such as axitinib (VEGFR), pazopanib (VEGFR, PDGFR, FGFR and the RET receptor) and lenvatinib (FGFR) but suffer from high toxicity, notably hypertension (Jimenez et al. 2020). The more promising one, cabozantinib (VEGFR and c-Met receptor), is currently evaluated in a phase II trial with encouraging preliminary results and unexpectedly, no severe hypertension or cardiovascular events (NCT02302833) (Jimenez et al. 2020). However, knowledge acquired in other types of cancers show that although TKI allows stabilizing tumor growth, anti-angiogenic agents rarely achieve complete responses, and it is common that after

Table 2 Therapeutic approaches for the treatment of SDH-mutated metastatic PPGL.

\begin{tabular}{|c|c|c|c|}
\hline Target & Drug & Type & Status \\
\hline \multirow{7}{*}{$\begin{array}{l}\text { Tyrosine kinase } \\
\text { receptors }\end{array}$} & Sunitinib & Phase II & Recruiting \\
\hline & FIRSTMAPP & Phase II & Published \\
\hline & SNIPP & & \\
\hline & Axitinib & Phase II & Recruiting and active, \\
\hline & Pazopanib & Phase II & not recruiting \\
\hline & Lenvatinib & Phase II & Terminated \\
\hline & Cabozantinib & Phase II & $\begin{array}{l}\text { Active, not recruiting } \\
\text { Recruiting }\end{array}$ \\
\hline $\mathrm{HIF} 2 \alpha$ & РT2977 & Phase I (one PGL) & Recruiting \\
\hline \multirow[t]{3}{*}{ Hypermethylation } & Decitabine & Pre-clinical (in vitro) & Published \\
\hline & HDAC & Pre-clinical (in vitro) & Published \\
\hline & Guadecitabine (SGI-110) & Phase II & $\begin{array}{l}\text { Completed, not yet } \\
\text { published }\end{array}$ \\
\hline \multirow{4}{*}{$\begin{array}{l}\text { Metabolomic } \\
\text { reprogramming }\end{array}$} & Metformin & Pre-clinical (in vitro) & Published \\
\hline & Dichloroacétate + Metformin & Pre-clinical (in vitro) & Published \\
\hline & PARPi: Talazoparib Olaparib & Pre-clinical (in vitro and & Published \\
\hline & Olaparib + Temozolomide & in vivo) & Not yet recruiting \\
\hline \multirow[t]{2}{*}{ Redox imbalance } & Ascorbate high dose & Pre-clinical (in vitro) & Personal \\
\hline & & $\begin{array}{l}\text { Pre-clinical (in vitro and } \\
\text { in vivo) }\end{array}$ & $\begin{array}{l}\text { communication } \\
\text { Published }\end{array}$ \\
\hline
\end{tabular}

Ref or clinical trial identifier on clinicaltrial.gov

NCT01371201

NCT00843037, O'Kane et al. 2019

NCT03839498 and

NCT01967576

NCT01340794

NCT03008369

NCT02302833

NCT02974738

Letouze et al. 2013

Martiniova et al. 2011

NCT03165721

Thakur et al. 2019

Florio et al. 2018

Pang et al. 2018, Sulkowski

et al. 2018

NCT04394858

Liu et al. 2020 
6-12 months of treatment, patients develop resistance. It requires the development of others alternative therapeutic strategies or the combination of antiangiogenic therapies with new treatments.

\section{Targeting pseudohypoxia}

Over the past decade, numerous data have suggested and then confirmed the oncogenic role of HIF $2 \alpha$ in metastatic PPGLs (Toledo et al. 2013, Morin et al. 2020). HIF2 $\alpha$, although a crucial target, was long considered to be pharmacologically inaccessible. Based on the structure of the HIF $2 \alpha$-ARNT/HIF1 $\beta$ dimer, two antagonists of HIF $2 \alpha$ (PT2385 and PT2977 (MK-6482)) were generated. These small molecules allosterically block the binding of HIF2 $\alpha$ to ARNT/HIF $\beta$, thereby inhibiting their transcriptional activity (Scheuermann et al. 2015).

Recent reports have shown very promising results of these two molecules in ccRCC, with a clear decrease in tumor growth in vitro and in vivo and a reduction in the expression of HIF2 $\alpha$ target genes (Chen et al. 2016, Cho et al. 2016, Xu et al. 2019). ccRCC is another example where tumorigenesis is mediated via a process of 'pseudohypoxia' through VHL mutations (Nickerson et al. 2008). These compounds were also found to be active in tumors progressing under sunitinib. A phase I study conducted with PT2385 in 51 patients with locally advanced or metastatic ccRCC previously treated with a TKI suggested its efficacy with a very good safety profile (Courtney et al. 2018). Several phase II studies are underway in ccRCC, alone (NCT03108066 or NCT03401788 only for VHL disease) or in combination with cabozantinib (NCT03634540) or everolimus (NCT04195750).

Given the very promising results of HIF $2 \alpha$ antagonists in ccRCC and the tumor mechanisms of PPGLs known to date, anti-HIF2 $\alpha$ appears to be good candidate for the treatment of metastatic PPGLs, in particular those mutated on the SDHB gene (Toledo 2017). In a currently recruiting basket trial of patients with advanced solid tumors treated with PT297, one patient with an SDHB mutant paraganglioma had stable disease $>25$ weeks with sustained decrease in normetanephrine levels (NCT02974738) (Papadopoulos et al. 2018). These data must however be counterbalanced by a recent in vitro study on a model of neuroblastoma that also shows overexpression of HIF $2 \alpha$, which found no effects on HIF $2 \alpha$ target genes expression and no major impact on cell survival in vitro or tumor growth in vivo upon treatment with PT2385 (Persson et al. 2020). In any case, the data are currently insufficient and other preclinical and clinical studies are necessary to evaluate this treatment, or the combination of the HIF $2 \alpha$ inhibitors with another, in metastatic PPGLs.

\section{Targeting epigenetic alteration}

Cyclophosphamide-dacarbazine-vincristine regimen is recommended as the standard chemotherapy for metastatic PPGL, with a partial response concerning tumor volume that can be achieved in about $37 \%$ in a metaanalysis (Niemeijer et al. 2014). However, temozolomide, the oral form of dacarbazine, seems to have higher response rates in patients with $S D H B$ mutations, with a longer PFS compared with patients without $S D H B$ mutation (19.7 vs 2.9 months). The efficiency of temozolomide, a DNA alkylating agent, is in fact dependent of the $\mathrm{O}(6)$-methylguanine-DNA-methyltransferase (MGMT) enzyme which repairs the DNA adducts induced by this treatment. In $S D H B$-mutated tumors, the silencing of MGMT promoter region by hypermethylation explains why $S D H B$ patients have better responses (Letouze et al. 2013, Hadoux et al. 2014).

The description of the hypermethylated phenotype of SDH-deficient tumors revealed the possibility of innovative epigenetic therapies involving DNA or histone demethylating agents. Decitabine, which acts as a hypomethylating agent through the inhibition of DNA-methyltransferase (DNMT), has been tested in $S d h b-/-$ mouse chromaffin cells and led to the reduction of their migratory capacities (Letouze et al. 2013). Histone Deacetylase (HDAC) inhibitors were found to enhance the amount of norepinephrine transporter and ${ }^{123}$ I-MIBG uptake in a mouse model of metastatic pheochromocytoma, leading to a possible combination of MIBG therapy and HDAC inhibitors (Martiniova et al. 2011). Preclinical studies with any of these treatments are still missing. However, a second-generation of DNA methylation inhibitor (guadecitabine, SGI-110), tested in acute myeloid leukemia (AML) and myelodysplastic syndrome, has been very recently evaluated by the NIH in a phase II study involving nine patients (seven with SDHdeficient GIST, one with SDH-deficient paraganglioma and one FH-mutated RCC (NCT03165721)). Results presented at the 2020 ASCO meeting unfortunately showed no complete or partial responses (Wedekind et al. 2020).

Another temptative option would be to restore $\alpha-K G$ dependent enzymes activity, by inducing an excess of $\alpha$-KG. In a mouse model of breast cancer-associated lung metastasis, an $\alpha$-KG-dependent dehydrogenase inhibitor (AA6) increased the intracellular level of $\alpha-K G$, thereby increasing TETs activity and reducing metastasis formation 
(Atlante et al. 2018). This promising treatment has never been tested in PPGLs so far.

\section{Targeting metabolic reprogramming}

Reprogrammed metabolic activities of PPGLs can also be exploited to treat them. Recently, IACS-010759, a clinical-grade small molecule inhibitor of oxidative phosphorylation (OXPHOS) through inhibition of mitochondrial complex I, has been tested with promising results in mouse models of AML and brain cancer (Molina et al. 2018). It inhibits proliferation and induces apoptosis through a combination of energy depletion and reduced aspartate production, leading to impaired nucleotide biosynthesis. IACS-010759 is currently evaluated in a phase I trial in solid tumor and relapsed/refractory AML and early results indicate that this treatment appears safe (NCT02882321 and NCT03291938). As explained before, upregulation of complex I and mitochondrial aspartate synthesis by pyruvate carboxylation are essential for Sdhb-/- chromaffin cells survival and proliferation, making IACS-010759 as potential drug for PPGL (LusseyLepoutre et al. 2015). Other OXPHOS inhibitors are under development, notably in glioblastoma (Shi et al. 2019).

Interestingly, metformin is another inhibitor of OXPHOS through complex I inhibition. Two in vitro studies performed on the cell lines derived from PPGL, mostly rat derived cells (PC12 cells), suggested an antiproliferative potential of metformin (Li et al. 2017, Thakur et al. 2019). These effects have to be confirmed in animal models and human studies. In a model of head and neck PGL cells with SDH loss, dichloroacétate (DCA), a structural analog of pyruvate, reduced cell viability alone or in combination with metformin through mechanisms involving pyruvate dehydrogenase kinase inhibition. It results in reactivation of pyruvate dehydrogenase promoting oxidative metabolism, decreasing extracellular lactate and increasing intracellular ROS levels (Florio et al. 2018). These treatments promote both cell cycle arrest and apoptosis in these cells and have to be explored further in animal models.

Finally, alterations of complex I activity in $S d h b-/-$ cells induce an upregulation of $\mathrm{NADH}$ dehydrogenase activity which alters $\mathrm{NAD}^{+} / \mathrm{NADH}$ balance resulting in increased $\mathrm{NAD}^{+}$availability and enhanced Poly(ADP)ribose polymerase (PARP) DNA repair (Pang et al. 2018). Similar to MGMT, PARP is a highly conserved enzyme which repairs single strand DNA breaks and stabilizes DNA replication. In parallel, succinate has been found to suppress the homologous recombination
DNA-repair pathway (that repairs double strand DNA breaks) through inhibition of the lysine demethylase KDM4B thus rendering renal cancer cells and tumor xenograft with $S D H B$-deficiency, all the more vulnerable to PARP inhibitors (Sulkowski et al. 2018, 2020). In mice with $S d h b-/-$ PPGL allografts, PARP inhibitors potentiated DNA damaging effects of temozolomide (but showed no effect alone) and reduced metastatic lesions, with prolonged overall survival of mice (Pang et al. 2018). Thereby, a new phase II testing the addition of olaparib to temozolomide will start soon (NCT04394858).

\section{Targeting redox imbalance}

Sdhb-/- cells exhibit dysregulation of oxygen metabolic pathways, leading to increased formation of ROS concomitantly with iron overload, suggesting that targeting the redox imbalance pathway could be a potential therapeutic approach. Very recently, we and others have demonstrated that pharmacologic ascorbate induces ROS overload in $S d h b-/$ - cells leading to impaired cell survival. Moreover, ascorbate delays Sdhb-KD allograft in vivo (Liu et al. 2020). In addition to redox imbalance, ascorbate targets other vulnerabilities of $S D H B$ tumors, that is the epigenetic reprogramming through TET activity and the oxygen-sensing regulation by inhibiting HIF activity (Ngo et al. 2019). Actually, several ongoing clinical trials are exploring the safety and efficacy of high-dose parenteral ascorbate in combination with chemotherapy or radiation, in various types of cancers such as glioblastoma, pancreatic, colorectal or non-small-cell lung cancers (Ngo et al. 2019). In all cases, high-dose i.v. ascorbate (generally $>1 \mathrm{~g} / \mathrm{kg}$ ) exhibits an excellent safety profile. Consequently, parenteral high-dose vitamin C, despite its controversial history, could to be a promising candidate for future treatment of SDH-related metastatic PPGL, probably in combination with others.

\section{Conclusion}

It has now been 20 years since the report by Baysal et al. of the first $S D H D$ gene mutation in a family with hereditary paraganglioma (Baysal et al. 2000), immediately followed by the identification of SDHC (Niemann \& Muller 2000) and SDHB (Astuti et al. 2001) gene mutations and later by the demonstration of the similar tumor suppressor roles of SDHAF2 (Bayley et al. 2010) and SDHA (Burnichon et al. 2010). Twenty years of clinical and basic research 
on SDH-related tumors have highlighted to complexity of the processes that link mitochondrial dysfunction and tumorigenesis. They have revealed a central role of oncometabolites in the biology of these tumors and improved our understanding of oxygen sensing and epigenetic reprogramming in cancer development. They have changed the management of patients with these rare tumors and the counseling and follow-up of their family members, thereby improving the prognosis of affected subjects (Buffet et al. 2019). They revealed many innovative therapeutic strategies that are or will soon be tested in clinical trials or in isolated individual and that will hopefully provide an increasing hope for the treatment of metastatic patients.

\section{Declaration of interest}

The authors declare that there is no conflict of interest that could be perceived as prejudicing the impartiality of this review.

\section{Funding}

Sophie Moog is the recipient of a fellowship from la Fondation pour la Recherche Médicale (FDM201806005916). The team has received funding from The Plan Cancer, Epigénétique et Cancer (EPIG201303 METABEPIC), The Paradifference Foundation, la Ligue Contre le Cancer (Equipe Labellisée) and the Cancer Research for Personalized Medicine - CARPEM project (Site de Recherche Intégré sur le Cancer - SIRIC).

\section{References}

Amar L, Baudin E, Burnichon N, Peyrard S, Silvera S, Bertherat J, Bertagna X, Schlumberger M, Jeunemaitre X, Gimenez-Roqueplo AP, et al. 2007 Succinate dehydrogenase B gene mutations predict survival in patients with malignant pheochromocytomas or paragangliomas. Journal of Clinical Endocrinology and Metabolism 92 3822-3828. (https://doi.org/10.1210/jc.2007-0709)

Amar L, Lussey-Lepoutre C, Lenders JWM, Djadi-Prat J, Plouin PF \& Steichen O 2016 MANAGEMENT OF ENDOCRINE DISEASE: Recurrence or new tumors after complete resection of pheochromocytomas and paragangliomas: a systematic review and meta-analysis. European Journal of Endocrinology 175 R135-R145. (https://doi.org/10.1530/EJE-16-0189)

Andronesi OC, Kim GS, Gerstner E, Batchelor T, Tzika AA, Fantin VR, Vander Heiden MG \& Sorensen AG 2012 Detection of 2-hydroxyglutarate in IDH-mutated glioma patients by in vivo spectral-editing and 2D correlation magnetic resonance spectroscopy. Science Translational Medicine 4 116ra4. (https://doi.org/10.1126/ scitranslmed.3002693)

Astuti D, Latif F, Dallol A, Dahia PL, Douglas F, George E, Skoldberg F, Husebye ES, Eng C \& Maher ER 2001 Gene mutations in the succinate dehydrogenase subunit SDHB cause susceptibility to familial pheochromocytoma and to familial paraganglioma. American Journal of Human Genetics 69 49-54. (https://doi. org/10.1086/321282)

Atlante S, Visintin A, Marini E, Savoia M, Dianzani C, Giorgis M, Sürün D, Maione F, Schnütgen F, Farsetti A, et al. 2018 $\alpha$-Ketoglutarate dehydrogenase inhibition counteracts breast cancer- associated lung metastasis. Cell Death and Disease 9 756. (https://doi. org/10.1038/s41419-018-0802-8)

Baudin E, Habra MA, Deschamps F, Cote G, Dumont F, Cabanillas M, Arfi-Roufe J, Berdelou A, Moon B, Al Ghuzlan A, et al. 2014 Therapy of endocrine disease: treatment of malignant pheochromocytoma and paraganglioma. European Journal of Endocrinology $17 \mathbf{1}$ R111-R122. (https://doi.org/10.1530/EJE-14-0113)

Bayley JP, Kunst HP, Cascon A, Sampietro ML, Gaal J, Korpershoek E, Hinojar-Gutierrez A, Timmers HJ, Hoefsloot LH, Hermsen MA, et al. 2010 SDHAF2 mutations in familial and sporadic paraganglioma and phaeochromocytoma. Lancet: Oncology 11 366-372. (https://doi. org/10.1016/S1470-2045(10)70007-3)

Baysal BE, Ferrell RE, Willett-Brozick JE, Lawrence EC, Myssiorek D, Bosch A, van der Mey A, Taschner PE, Rubinstein WS, Myers EN, et al. 2000 Mutations in SDHD, a mitochondrial complex II gene, in hereditary paraganglioma. Science 287 848-851. (https://doi. org/10.1126/science.287.5454.848)

Benn DE, Richardson AL, Marsh DJ \& Robinson BG 2006 Genetic testing in pheochromocytoma- and paraganglioma-associated syndromes. Annals of the New York Academy of Sciences 1073 104-111. (https:// doi.org/10.1196/annals.1353.011)

Bezawork-Geleta A, Wen H, Dong L, Yan B, Vider J, Boukalova S, Krobova L, Vanova K, Zobalova R, Sobol M, et al. 2018 Alternative assembly of respiratory complex II connects energy stress to metabolic checkpoints. Nature Communications 9 2221. (https://doi. org/10.1038/s41467-018-04603-z)

Briere JJ, Favier J, Benit P, El Ghouzzi V, Lorenzato A, Rabier D, Di Renzo MF, Gimenez-Roqueplo AP \& Rustin P 2005 Mitochondrial succinate is instrumental for HIF1alpha nuclear translocation in SDHAmutant fibroblasts under normoxic conditions. Human Molecular Genetics 14 3263-3269. (https://doi.org/10.1093/hmg/ddi359)

Buffet A, Morin A, Castro-Vega LJ, Habarou F, Lussey-Lepoutre C, Letouze E, Lefebvre H, Guilhem I, Haissaguerre M, Raingeard I, et al. 2018 Germline mutations in the mitochondrial 2-oxoglutarate/ malate carrier SLC25A11 gene confer a predisposition to metastatic paragangliomas. Cancer Research 78 1914-1922 (https://doi. org/10.1158/0008-5472.CAN-17-2463)

Buffet A, Ben Aim L, Leboulleux S, Drui D, Vezzosi D, Libé R, Ajzenberg C, Bernardeschi D, Cariou B, Chabolle F, et al. 2019 Positive impact of genetic test on the management and outcome of patients with paraganglioma and/or pheochromocytoma. Journal of Clinical Endocrinology and Metabolism 104 1109-1118. (https://doi. org/10.1210/jc.2018-02411)

Buffet A, Burnichon N, Favier J \& Gimenez-Roqueplo AP 2020 An overview of 20 years of genetic studies in pheochromocytoma and paraganglioma. Best Practice and Research: Clinical Endocrinology and Metabolism 34 101416. (https://doi.org/10.1016/j.beem.2020.101416)

Burnichon N, Rohmer V, Amar L, Herman P, Leboulleux S, Darrouzet V, Niccoli P, Gaillard D, Chabrier G, Chabolle F, et al. 2009 The succinate dehydrogenase genetic testing in a large prospective series of patients with paragangliomas. Journal of Clinical Endocrinology and Metabolism 94 2817-2827. (https://doi.org/10.1210/jc.2008-2504)

Burnichon N, Briere JJ, Libe R, Vescovo L, Riviere J, Tissier F, Jouanno E, Jeunemaitre X, Benit P, Tzagoloff A, et al. 2010 SDHA is a tumor suppressor gene causing paraganglioma. Human Molecular Genetics 19 3011-3020. (https://doi.org/10.1093/hmg/ddq206)

Burnichon N, Mazzella JM, Drui D, Amar L, Bertherat J, Coupier I, Delemer B, Guilhem I, Herman P, Kerlan V, et al. 2017 Risk assessment of maternally inherited SDHD paraganglioma and phaeochromocytoma. Journal of Medical Genetics 54 125-133. (https://doi.org/10.1136/jmedgenet-2016-104297)

Cardaci S, Zheng L, MacKay G, van den Broek NJ, MacKenzie ED, Nixon C, Stevenson D, Tumanov S, Bulusu V, Kamphorst JJ, et al. 2015 Pyruvate carboxylation enables growth of SDH-deficient cells by supporting aspartate biosynthesis. Nature Cell Biology 17 1317-1326. (https://doi.org/10.1038/ncb3233) https://erc.bioscientifica.com

https://doi.org/10.1530/ERC-20-0346 (c) 2020 Society for Endocrinology Published by Bioscientifica Ltd. Printed in Great Britain 
Casey RT, McLean MA, Madhu B, Challis BG, Ten Hoopen R, Roberts T, Clark GR, Pittfield D, Simpson HL, Bulusu VR, et al. 2018 Translating in vivo metabolomic analysis of succinate dehydrogenase deficient tumours into clinical utility. JCO Precision Oncology 2 1-12. (https:// doi.org/10.1200/PO.17.00191)

Castro-Vega LJ, Buffet A, De Cubas AA, Cascón A, Menara M, Khalifa E, Amar L, Azriel S, Bourdeau I, Chabre O, et al. 2014 Germline mutations in $\mathrm{FH}$ confer predisposition to malignant pheochromocytomas and paragangliomas. Human Molecular Genetics 23 2440-2446. (https://doi.org/10.1093/hmg/ddt639)

Cervera AM, Bayley JP, Devilee P \& McCreath KJ 2009 Inhibition of succinate dehydrogenase dysregulates histone modification in mammalian cells. Molecular Cancer 8 89. (https://doi. org/10.1186/1476-4598-8-89)

Chen W, Hill H, Christie A, Kim MS, Holloman E, Pavia-Jimenez A, Homayoun F, Ma Y, Patel N, Yell P, et al. 2016 Targeting renal cell carcinoma with a HIF-2 antagonist. Nature 539 112-117. (https:// doi.org/10.1038/nature19796)

Cho H, Du X, Rizzi JP, Liberzon E, Chakraborty AA, Gao W, Carvo I, Signoretti S, Bruick RK, Josey JA, et al. 2016 On-target efficacy of a HIF-2 $\alpha$ antagonist in preclinical kidney cancer models. Nature 539 107-111. (https://doi.org/10.1038/nature19795)

Choi C, Ganji SK, DeBerardinis RJ, Hatanpaa KJ, Rakheja D, Kovacs Z, Yang XL, Mashimo T, Raisanen JM, Marin-Valencia I, et al. 2012 2-Hydroxyglutarate detection by magnetic resonance spectroscopy in IDH-mutated patients with gliomas. Nature Medicine 18 624-629. (https://doi.org/10.1038/nm.2682)

Courtney KD, Infante JR, Lam ET, Figlin RA, Rini BI, Brugarolas J, Zojwalla NJ, Lowe AM, Wang K, Wallace EM, et al. 2018 Phase I dose-escalation trial of PT2385, a first-in-class hypoxia-inducible Factor- $2 \alpha$ antagonist in patients With previously treated advanced clear cell renal cell carcinoma. Journal of Clinical Oncology 36 867-874. (https://doi.org/10.1200/JCO.2017.74.2627)

de Cubas AA, Korpershoek E, Inglada-Pérez L, Letouzé E, CurrásFreixes M, Fernández AF, Comino-Méndez I, Schiavi F, Mancikova V, Eisenhofer G, et al. 2015 DNA methylation profiling in pheochromocytoma and paraganglioma reveals diagnostic and prognostic markers. Clinical Cancer Research 21 3020-3030. (https:// doi.org/10.1158/1078-0432.CCR-14-2804)

Eisenhofer G, Klink B, Richter S, Lenders JW \& Robledo M 2017 Metabologenomics of phaeochromocytoma and paraganglioma: an integrated approach for personalised biochemical and genetic testing. Clinical Biochemist: Reviews 38 69-100.

Favier J \& Gimenez-Roqueplo AP 2010 Pheochromocytomas: the (pseudo)-hypoxic hypothesis. Best Practice and Research: Clinical Endocrinology and Metabolism 24 957-968. (https://doi.org/10.1016/j. beem.2010.10.004)

Favier J, Briere JJ, Burnichon N, Riviere J, Vescovo L, Benit P, GiscosDouriez I, De Reynies A, Bertherat J, Badoual C, et al. 2009 The Warburg effect is genetically determined in inherited pheochromocytomas. PLOS ONE 4 e7094. (https://doi.org/10.1371/ journal.pone.0007094)

Favier J, Amar L \& Gimenez-Roqueplo AP 2015 Paraganglioma and phaeochromocytoma: from genetics to personalized medicine. Nature Reviews: Endocrinology 11 101-111. (https://doi.org/10.1038/ nrendo.2014.188)

Fishbein L, Leshchiner I, Walter V, Danilova L, Robertson AG, Johnson AR, Lichtenberg TM, Murray BA, Ghayee HK, Else T, et al. 2017 Comprehensive molecular characterization of pheochromocytoma and paraganglioma. Cancer Cell 31 181-193. (https://doi.org/10.1016/j.ccell.2017.01.001)

Florio R, De Lellis L, Veschi S, Verginelli F, di Giacomo V, Gallorini M, Perconti S, Sanna M, Mariani-Costantini R, Natale A, et al. 2018 Effects of dichloroacetate as single agent or in combination with GW6471 and metformin in paraganglioma cells. Scientific Reports 8 13610. (https://doi.org/10.1038/s41598-018-31797-5)
Gaal J, Stratakis CA, Carney JA, Ball ER, Korpershoek E, Lodish MB, Levy I, Xekouki P, van Nederveen FH, den Bakker MA, et al. 2011 SDHB immunohistochemistry: a useful tool in the diagnosis of Carney-Stratakis and Carney triad gastrointestinal stromal tumors. Modern Pathology 24 147-151. (https://doi.org/10.1038/ modpathol.2010.185)

Gill AJ, Benn DE, Chou A, Clarkson A, Muljono A, Meyer-Rochow GY, Richardson AL, Sidhu SB, Robinson BG \& Clifton-Bligh RJ 2010 Immunohistochemistry for SDHB triages genetic testing of SDHB, SDHC, and SDHD in paraganglioma-pheochromocytoma syndromes. Human Pathology 41 805-814. (https://doi.org/10.1016/j. humpath.2009.12.005)

Gill AJ, Pachter NS, Clarkson A, Tucker KM, Winship IM, Benn DE, Robinson BG \& Clifton-Bligh RJ 2011 Renal tumors and hereditary pheochromocytoma-paraganglioma syndrome type 4. New England Journal of Medicine 364 885-886. (https://doi.org/10.1056/ NEJMc1012357)

Gimenez-Roqueplo AP, Favier J, Rustin P, Mourad JJ, Plouin PF, Corvol P, Rötig A \& Jeunemaitre X 2001 The R22X mutation of the SDHD gene in hereditary paraganglioma abolishes the enzymatic activity of complex II in the mitochondrial respiratory chain and activates the hypoxia pathway. American Journal of Human Genetics 69 1186-1197. (https://doi.org/10.1086/324413)

Guzy RD, Sharma B, Bell E, Chandel NS \& Schumacker PT 2008 Loss of the SdhB, but not the SdhA, subunit of complex II triggers reactive oxygen species-dependent hypoxia-inducible factor activation and tumorigenesis. Molecular and Cellular Biology 28 718-731. (https:// doi.org/10.1128/MCB.01338-07)

Hadoux J, Favier J, Scoazec JY, Leboulleux S, Al Ghuzlan A, Caramella C, Déandreis D, Borget I, Loriot C, Chougnet C, et al. 2014 SDHB mutations are associated with response to temozolomide in patients with metastatic pheochromocytoma or paraganglioma. International Journal of Cancer 135 2711-2720. (https://doi.org/10.1002/ijc.28913)

Hamidi O, Young WF, Gruber L, Smestad J, Yan Q, Ponce OJ, Prokop L, Murad MH \& Bancos I 2017 Outcomes of patients with metastatic phaeochromocytoma and paraganglioma: a systematic review and meta-analysis. Clinical Endocrinology 87 440-450. (https://doi. org/10.1111/cen.13434)

Hanahan D \& Weinberg RA 2011 Hallmarks of cancer: the next generation. Cell 144 646-674. (https://doi.org/10.1016/j. cell.2011.02.013)

Hescot S, Curras-Freixes M, Deutschbein T, van Berkel A, Vezzosi D, Amar L, de la Fouchardière C, Valdes N, Riccardi F, Do Cao C, et al. 2019 Prognosis of malignant pheochromocytoma and paraganglioma (MAPP-Prono study): a European Network for the Study of Adrenal Tumors Retrospective Study. Journal of Clinical Endocrinology and Metabolism 104 2367-2374. (https://doi.org/10.1210/jc.2018-01968)

Hobert JA, Mester JL, Moline J \& Eng C 2012 Elevated plasma succinate in PTEN, SDHB, and SDHD mutation-positive individuals. Genetics in Medicine 14 616-619. (https://doi.org/10.1038/gim.2011.63)

Hoekstra AS, de Graaff MA, Briaire-de Bruijn IH, Ras C, Seifar RM, van Minderhout I, Cornelisse CJ, Hogendoorn PCW, Breuning MH, Suijker J, et al. 2015 Inactivation of SDH and FH cause loss of $5 \mathrm{hmC}$ and increased $\mathrm{H} 3 \mathrm{~K} 9 \mathrm{me} 3$ in paraganglioma/pheochromocytoma and smooth muscle tumors. Oncotarget 6 38777-38788. (https://doi. org/10.18632/oncotarget.6091)

Imperiale A, Moussallieh FM, Roche P, Battini S, Cicek AE, Sebag F, Brunaud L, Barlier A, Elbayed K, Loundou A, et al. 2015 Metabolome profiling by HRMAS NMR spectroscopy of pheochromocytomas and paragangliomas detects SDH deficiency: clinical and pathophysiological implications. Neoplasia 17 55-65. (https://doi. org/10.1016/j.neo.2014.10.010)

Islam MS, Leissing TM, Chowdhury R, Hopkinson RJ \& Schofield CJ 2018 2-Oxoglutarate-dependent oxygenases. Annual Review of Biochemistry 87 585-620. (https://doi.org/10.1146/annurevbiochem-061516-044724) 
Jimenez C, Fazeli S \& Román-Gonzalez A 2020 Antiangiogenic therapies for pheochromocytoma and paraganglioma. Endocrine-Related Cancer 27 R239-R254. (https://doi.org/10.1530/ERC-20-0043)

Killian JK, Kim SY, Miettinen M, Smith C, Merino M, Tsokos M, Quezado M, Smith WI, Jahromi MS, Xekouki P, et al. 2013 Succinate dehydrogenase mutation underlies global epigenomic divergence in gastrointestinal stromal tumor. Cancer Discovery 3 648-657. (https:// doi.org/10.1158/2159-8290.CD-13-0092)

Kim E, Rath EM, Tsang VHM, Duff AP, Robinson BG, Church WB, Benn DE, Dwight T \& Clifton-Bligh RJ 2015 Structural and functional consequences of succinate dehydrogenase subunit B mutations. Endocrine-Related Cancer 22 387-397. (https://doi. org/10.1530/ERC-15-0099)

Klučková K, Thakker A, Vettore L, Escribano-Gonzalez C, Hindshaw RL, Tearle JLE, Goncalves J, Kaul B, Lavery GG, Favier J, et al. 2020 Succinate dehydrogenase deficiency in a chromaffin cell model retains metabolic fitness through the maintenance of mitochondria NADH oxidoreductase function. FASEB Journal 34 303-315. (https:// doi.org/10.1096/fj.201901456R)

Knudson AG 1971 Mutation and cancer: statistical study of retinoblastoma. PNAS $\mathbf{6 8}$ 820-823. (https://doi.org/10.1073/ pnas.68.4.820)

Korpershoek E, Favier J, Gaal J, Burnichon N, van Gessel B, Oudijk L, Badoual C, Gadessaud N, Venisse A, Bayley JP, et al. 2011 SDHA immunohistochemistry detects germline SDHA gene mutations in apparently sporadic paragangliomas and pheochromocytomas. Journal of Clinical Endocrinology and Metabolism 96 E1472-E1476. (https://doi.org/10.1210/jc.2011-1043)

Lam AK-Y 2017 Update on adrenal tumours in 2017 World Health Organization (WHO) of endocrine tumours. Endocrine Pathology 28 213-227. (https://doi.org/10.1007/s12022-017-9484-5)

Lenders JWM, Kerstens MN, Amar L, Prejbisz A, Robledo M, Taieb D, Pacak K, Crona J, Zelinka T, Mannelli M, et al. 2020 Genetics, diagnosis, management and future directions of research of phaeochromocytoma and paraganglioma: a position statement and consensus of the working group on endocrine hypertension of the European Society of Hypertension. Journal of Hypertension $\mathbf{3 8}$ 1443-1456. (https://doi.org/10.1097/HJH.0000000000002438)

Lendvai N, Pawlosky R, Bullova P, Eisenhofer G, Patocs A, Veech RL \& Pacak K 2014 Succinate-to-fumarate ratio as a new metabolic marker to detect the presence of SDHB/D-related paraganglioma: initial experimental and ex vivo findings. Endocrinology 155 27-32. (https:// doi.org/10.1210/en.2013-1549)

Letouze E, Martinelli C, Loriot C, Burnichon N, Abermil N, Ottolenghi C, Janin M, Menara M, Nguyen AT, Benit P, et al. 2013 SDH mutations establish a hypermethylator phenotype in paraganglioma. Cancer Cell 23 739-752. (https://doi.org/10.1016/j. ccr.2013.04.018)

Li M, Jiang X, Su T, Jiang L, Zhou W \& Wang W 2017 Metformin suppresses proliferation and viability of rat pheochromocytoma cells. Medical Science Monitor 23 3253-3260. (https://doi.org/10.12659/ msm.903348)

Liu Y, Pang Y, Zhu B, Uher O, Caisova V, Huynh TT, Taieb D, Hadrava Vanova K, Ghayee HK, Neuzil J, et al. 2020 Therapeutic targeting of SDHB-mutated pheochromocytoma/paraganglioma with pharmacologic ascorbic acid. Clinical Cancer Research 26 3868-3880. (https://doi.org/10.1158/1078-0432.CCR-19-2335)

Lorendeau D, Rinaldi G, Boon R, Spincemaille P, Metzger K, Jager C, Christen S, Dong X, Kuenen S, Voordeckers K, et al. 2017 Dual loss of succinate dehydrogenase (SDH) and complex I activity is necessary to recapitulate the metabolic phenotype of SDH mutant tumors. Metabolic Engineering 43 187-197. (https://doi.org/10.1016/j. ymben.2016.11.005)

Lussey-Lepoutre C, Hollinshead KER, Ludwig C, Menara M, Morin A, Castro-Vega LJ, Parker SJ, Janin M, Martinelli C, Ottolenghi C, et al. 2015 Loss of succinate dehydrogenase activity results in dependency on pyruvate carboxylation for cellular anabolism. Nature Communications 6 8784. (https://doi.org/10.1038/ncomms9784)

Lussey-Lepoutre C, Bellucci A, Morin A, Buffet A, Amar L, Janin M, Ottolenghi C, Zinzindohoué F, Autret G, Burnichon N, et al. 2016 In vivo detection of succinate by magnetic resonance spectroscopy as a hallmark of SDHx mutations in paraganglioma. Clinical Cancer Research 22 1120-1129. (https://doi.org/10.1158/1078-0432.CCR-151576)

Lussey-Lepoutre C, Bellucci A, Burnichon N, Amar L, Buffet A, Drossart T, Fontaine S, Clement O, Benit P, Rustin P, et al. 2020 Succinate detection using in vivo $1 \mathrm{H}$-MR spectroscopy identifies germline and somatic SDHx mutations in paragangliomas. European Journal of Nuclear Medicine and Molecular Imaging 47 1510-1517. (https://doi.org/10.1007/s00259-019-04633-9)

Martiniova L, Perera SM, Brouwers FM, Alesci S, Abu-Asab M, Marvelle AF, Kiesewetter DO, Thomasson D, Morris JC, Kvetnansky R, et al. 2011 Increased uptake of [123I]metaiodobenzylguanidine, $\left[{ }^{18} \mathrm{~F}\right]$ fluorodopamine, and $\left[{ }^{3} \mathrm{H}\right]$ norepinephrine in mouse pheochromocytoma cells and tumors after treatment with the histone deacetylase inhibitors. Endocrine-Related Cancer 18 143-157. (https://doi.org/10.1677/ERC-10-0090)

Menara M, Oudijk L, Badoual C, Bertherat J, Lepoutre-Lussey C, Amar L, Iturrioz X, Sibony M, Zinzindohoué F, de Krijger R, et al. 2015 SDHD immunohistochemistry: a new tool to validate SDHx mutations in pheochromocytoma/paraganglioma. Journal of Clinical Endocrinology and Metabolism 100 E287-E291. (https://doi.org/10.1210/jc.20141870)

Molina JR, Sun Y, Protopopova M, Gera S, Bandi M, Bristow C, McAfoos T, Morlacchi P, Ackroyd J, Agip A-NA, et al. 2018 An inhibitor of oxidative phosphorylation exploits cancer vulnerability. Nature Medicine 24 1036-1046. (https://doi.org/10.1038/s41591-018-0052-4)

Morin A, Goncalves J, Moog S, Castro-Vega LJ, Job S, Buffet A, Fontenille MJ, Woszczyk J, Gimenez-Roqueplo AP, Letouzé E, et al. 2020 TET-mediated hypermethylation primes SDH-deficient cells for HIF $2 \alpha$-driven mesenchymal transition. Cell Reports 30 4551-4566.e7. (https://doi.org/10.1016/j.celrep.2020.03.022)

Ngo B, Van Riper JM, Cantley LC \& Yun J 2019 Targeting cancer vulnerabilities with high-dose vitamin C. Nature Reviews: Cancer 19 271-282. (https://doi.org/10.1038/s41568-019-0135-7)

Nickerson ML, Jaeger E, Shi Y, Durocher JA, Mahurkar S, Zaridze D, Matveev V, Janout V, Kollarova H, Bencko V, et al. 2008 Improved identification of von Hippel-Lindau gene alterations in clear cell renal tumors. Clinical Cancer Research 14 4726-4734. (https://doi. org/10.1158/1078-0432.CCR-07-4921)

Niemann S \& Muller U 2000 Mutations in SDHC cause autosomal dominant paraganglioma, type 3. Nature Genetics 26 268-270. (https://doi.org/10.1038/81551)

Niemeijer ND, Alblas G, van Hulsteijn LT, Dekkers OM \& Corssmit EPM 2014 Chemotherapy with cyclophosphamide, vincristine and dacarbazine for malignant paraganglioma and pheochromocytoma: systematic review and meta-analysis. Clinical Endocrinology $\mathbf{8 1}$ 642-651. (https://doi.org/10.1111/cen.12542)

O'Kane GM, Ezzat S, Joshua AM, Bourdeau I, Leibowitz-Amit R, Olney HJ, Krzyzanowska M, Reuther D, Chin S, Wang L, et al. 2019 A phase 2 trial of sunitinib in patients with progressive paraganglioma or pheochromocytoma: the SNIPP trial. British Journal of Cancer 120 1113-1119. (https://doi.org/10.1038/s41416-0190474-x)

Oudijk L, Gaal J, Korpershoek E, van Nederveen FH, Kelly L, Schiavon G, Verweij J, Mathijssen RHJ, den Bakker MA, Oldenburg RA, et al. 2013 SDHA mutations in adult and pediatric wild-type gastrointestinal stromal tumors. Modern Pathology 26 456-463. (https://doi.org/10.1038/modpathol.2012.186)

Pang Y, Lu Y, Caisova V, Liu Y, Bullova P, Huynh TT, Zhou Y, Yu D, Frysak Z, Hartmann I, et al. 2018 Targeting NAD+/PARP DNA repair pathway as a novel therapeutic approach to SDHB-mutated cluster I https://erc bioscientifica com

https://doi.org/10.1530/ERC-20-0346 (c) 2020 Society for Endocrinology Published by Bioscientifica Ltd. Printed in Great Britain 
pheochromocytoma and paraganglioma. Clinical Cancer Research 24 3423-3432. (https://doi.org/10.1158/1078-0432.CCR-17-3406)

Papadopoulos KP, Jonasch E, Zojwalla NJ, Wang K \& Bauer TM 2018 A first-in-human phase 1 dose-escalation trial of the oral HIF-2a inhibitor PT2977 in patients with advanced solid tumors. Journal of Clinical Oncology 36 2508-2508. (https://doi.org/10.1200/ JCO.2018.36.15_suppl.2508)

Papathomas TG, Oudijk L, Persu A, Gill AJ, van Nederveen F, Tischler AS, Tissier F, Volante M, Matias-Guiu X, Smid M, et al. 2015 SDHB/SDHA immunohistochemistry in pheochromocytomas and paragangliomas: a multicenter interobserver variation analysis using virtual microscopy: a multinational study of the European Network for the Study of Adrenal Tumors (ENS@T) Modern Pathology 28 807-821. (https://doi.org/10.1038/modpathol.2015.41)

Persson CU, von Stedingk K, Fredlund E, Bexell D, Påhlman S, Wigerup C \& Mohlin S 2020 ARNT-dependent HIF-2 transcriptional activity is not sufficient to regulate downstream target genes in neuroblastoma. Experimental Cell Research 388 111845. (https://doi. org/10.1016/j.yexcr.2020.111845)

Pollard PJ, Brière JJ, Alam NA, Barwell J, Barclay E, Wortham NC, Hunt T, Mitchell M, Olpin S, Moat SJ, et al. 2005 Accumulation of Krebs cycle intermediates and over-expression of HIF1alpha in tumours which result from germline FH and SDH mutations. Human Molecular Genetics 14 2231-2239. (https://doi.org/10.1093/hmg/ ddi227)

Rao JU, Engelke UFH, Rodenburg RJT, Wevers RA, Pacak K, Eisenhofer G, Qin N, Kusters B, Goudswaard AG, Lenders JWM, et al. 2013 Genotype-specific abnormalities in mitochondrial function associate with distinct profiles of energy metabolism and catecholamine content in pheochromocytoma and paraganglioma. Clinical Cancer Research 19 3787-3795. (https://doi.org/10.1158/1078-0432.CCR-12-3922)

Richter S, Peitzsch M, Rapizzi E, Lenders JW, Qin N, de Cubas AA, Schiavi F, Rao JU, Beuschlein F, Quinkler M, et al. 2014 Krebs cycle metabolite profiling for identification and stratification of pheochromocytomas/paragangliomas due to succinate dehydrogenase deficiency. Journal of Clinical Endocrinology and Metabolism 99 3903-3911. (https://doi.org/10.1210/jc.2014-2151)

Rustin P, Chretien D, Bourgeron T, Gérard B, Rötig A, Saudubray JM \& Munnich A 1994 Biochemical and molecular investigations in respiratory chain deficiencies. Clinica Chimica Acta: International Journal of Clinical Chemistry 228 35-51. (https://doi. org/10.1016/0009-8981(94)90055-8)

Scheuermann TH, Stroud D, Sleet CE, Bayeh L, Shokri C, Wang H, Caldwell CG, Longgood J, MacMillan JB, Bruick RK, et al. 2015 Isoform-selective and stereoselective inhibition of hypoxia inducible factor-2. Journal of Medicinal Chemistry 58 5930-5941. (https://doi. org/10.1021/acs.jmedchem.5b00529)

Selak MA, Armour SM, MacKenzie ED, Boulahbel H, Watson DG, Mansfield KD, Pan Y, Simon MC, Thompson CB \& Gottlieb E 2005 Succinate links TCA cycle dysfunction to oncogenesis by inhibiting HIF-alpha prolyl hydroxylase. Cancer Cell 7 77-85. (https://doi. org/10.1016/j.ccr.2004.11.022)

Selak MA, Durán RV \& Gottlieb E 2006 Redox stress is not essential for the pseudo-hypoxic phenotype of succinate dehydrogenase deficient cells. Biochimica et Biophysica Acta 1757 567-572. (https://doi. org/10.1016/j.bbabio.2006.05.015)

Shi Y, Lim SK, Liang Q, Iyer SV, Wang HY, Wang Z, Xie X, Sun D, Chen YJ, Tabar V, et al. 2019 Gboxin is an oxidative phosphorylation inhibitor that targets glioblastoma. Nature 567 341-346. (https://doi. org/10.1038/s41586-019-0993-x)
Sulkowski PL, Sundaram RK, Oeck S, Corso CD, Liu Y, Noorbakhsh S, Niger M, Boeke M, Ueno D, Kalathil AN, et al. 2018 Krebs-cycledeficient hereditary cancer syndromes are defined by defects in homologous-recombination DNA repair. Nature Genetics 50 1086-1092. (https://doi.org/10.1038/s41588-018-0170-4)

Sulkowski PL, Oeck S, Dow J, Economos NG, Mirfakhraie L, Liu Y, Noronha K, Bao X, Li J, Shuch BM, et al. 2020 Oncometabolites suppress DNA repair by disrupting local chromatin signalling. Nature 582 586-591. (https://doi.org/10.1038/s41586-020-2363-0)

Thakur S, Daley B \& Klubo-Gwiezdzinska J 2019 The role of an antidiabetic drug metformin in the treatment of endocrine tumors. Journal of Molecular Endocrinology 63 R17-R35. (https://doi. org/10.1530/JME-19-0083)

Toledo RA 2017 New HIF2 $\alpha$ inhibitors: potential implications as therapeutics for advanced pheochromocytomas and paragangliomas. Endocrine-Related Cancer 24 C9-C19. (https://doi.org/10.1530/ERC16-0479)

Toledo RA \& Dahia PL 2015 Next-generation sequencing for the diagnosis of hereditary pheochromocytoma and paraganglioma syndromes. Current Opinion in Endocrinology, Diabetes, and Obesity 22 169-179. (https://doi.org/10.1097/MED.0000000000000150)

Toledo RA, Qin Y, Srikantan S, Morales NP, Li Q, Deng Y, Kim SW, Pereira MAA, Toledo SPA, Su X, et al. 2013 In vivo and in vitro oncogenic effects of HIF2A mutations in pheochromocytomas and paragangliomas. Endocrine-Related Cancer 20 349-359. (https://doi. org/10.1530/ERC-13-0101)

van Nederveen FH, Gaal J, Favier J, Korpershoek E, Oldenburg RA, de Bruyn EMCA, Sleddens HFBM, Derkx P, Rivière J, Dannenberg H, et al. 2009 An immunohistochemical procedure to detect patients with paraganglioma and phaeochromocytoma with germline SDHB, SDHC, or SDHD gene mutations: a retrospective and prospective analysis. Lancet: Oncology 10 764-771. (https://doi.org/10.1016/ S1470-2045(09)70164-0)

Varoquaux A, le Fur Y, Imperiale A, Reyre A, Montava M, Fakhry N, Namer IJ, Moulin G, Pacak K, Guye M, et al. 2015 Magnetic resonance spectroscopy of paragangliomas: new insights into in vivo metabolomics. Endocrine-Related Cancer 22 M1-M8. (https://doi. org/10.1530/ERC-15-0246)

Wallace PW, Conrad C, Brückmann S, Pang Y, Caleiras E, Murakami M, Korpershoek E, Zhuang Z, Rapizzi E, Kroiss M, et al. 2020 Metabolomics, machine learning and immunohistochemistry to predict succinate dehydrogenase mutational status in phaeochromocytomas and paragangliomas. Journal of Pathology $\mathbf{2 5 1}$ 378-387. (https://doi.org/10.1002/path.5472)

Warburg O 1956 On respiratory impairment in cancer cells. Science $\mathbf{1 2 4}$ 269-270.

Wedekind MF, Del Rivero J, Arnaldez FI, Srinivasan R, Spencer M, Steinberg SM, Peer CJ, Figg WD, Killian JK, Meltzer PS, et al. 2020 A phase II trial of the DNA methyl transferase inhibitor, SGI-110 (Guadecitabine), in children and adults with SDH-deficient GIST, pheochromocytoma, and paraganglioma, and HLRCC-associated kidney cancer. Journal of Clinical Oncology 38 (Supplement) abstr 11540. (https://doi.org/10.1200/JCO.2020.38.15_suppl.11540)

Xu R, Wang K, Rizzi JP, Huang H, Grina JA, Schlachter ST, Wang B, Wehn PM, Yang H, Dixon DD, et al. 2019 3-[(1S,2S,3R)-2,3-difluoro1-hydroxy-7-methylsulfonylindan-4-yl]oxy-5-fluorobenzonitrile (PT2977), a hypoxia-inducible factor $2 \alpha$ (HIF-2 $\alpha$ ) inhibitor for the treatment of clear cell renal cell carcinoma. Journal of Medicinal Chemistry 62 6876-6893. (https://doi.org/10.1021/acs. jmedchem.9b00719)

Received in final form 21 September 2020

Accepted 29 September 2020

Accepted Manuscript published online 29 September 2020 https://erc.bioscientifica.com

https://doi.org/10.1530/ERC-20-0346 (c) 2020 Society for Endocrinology Published by Bioscientifica Ltd. Printed in Great Britain 